\title{
Normalizing Difference: Emotional intelligence and diversity management competence in healthcare managers
}

\author{
Adebukola E. Oyewunmi iD \\ Covenant University (Nigeria) \\ adebukola.oyewunmi@covenantuniversity.edu.ng
}

Received April, 2017

Accepted April, 2018

\begin{abstract}
Purpose: The diverse workforce presents an array of complexities which necessitates the deployment of specific managerial competencies. Empirical evidences have indicated the role of emotional intelligence in the enhancement of abilities. Thus, this study investigated the relationship between emotional intelligence and diversity management competence amongst healthcare managers in Southwest Nigeria.
\end{abstract}

Design/methodology: The descriptive survey method was adopted for the study. A total of 360 respondents completed the structured questionnaire titled Emotional Intelligence and Diversity Management Competence Questionnaire (EIDMCQ). Data was analyzed using descriptive statistics, hierarchical regression model and Structural Equation Model (SEM).

Findings: A positive significant relationship was found between emotional intelligence and diversity management competence. Further findings on the dynamics of relationships between the constructs of emotional intelligence and diversity management competence are presented in the study.

Practical implications: As difference is the reality of modern organizations, it is important to conceptualize it as normal and positive. Emotional intelligence is recommended as a critical tool to normalize the individual perceptions of difference. The re-assessment of the functions of managers must be followed by total commitment to capacity building in emotional intelligence, as well as the reengineering of organizational and national cultures to promote equal opportunities, inclusion and diversity leveraging.

Originality/value: This study pioneers research on emotional intelligence and diversity management competence in Nigeria's public healthcare sector. It conceptualizes diversity management on an individual- managerial level. Practical interventions are provided to enhance the application of specific competencies to optimize a diverse workplace.

Keywords: Emotional Intelligence, Diversity, Diversity Management, Healthcare, Leadership, Managers

Jel Codes: J24, M12

\section{Introduction}

The existence of any organization is usually geared towards the achievement of set objectives. As a subsystem, the organization operates within an environment and is therefore subject to environmental factors. These internal and external factors have the potential to impact on performance outcomes. As agents of an 
organization, managers have a measure of control over the internal milieu of their organization. A major component of the organization's internal environment is its human asset, which is central to the viability and survival of the organization. Hence, there is a critical need to understand and embrace the heterogeneous nature of the workforce (Ashkanasy, Hartel \& Daus, 2002; Meyer \& Bromley, 2013).

The functions of management and the convoluted demands of the modern workplace requires managers to possess a wide range of competencies, which refer to performance capabilities that distinguish effective from ineffective managers within the organizational context. Managerial competencies include intra-personal, interpersonal, leadership, and business skills. A manager's intra-personal and inter-personal competencies will influence the ability to effectively relate with and lead the diverse workforce. Therefore, human skills are crucial for the survival of contemporary organizations. If organizations select and evaluate managers based solely on cognitive abilities and business skills, whilst ignoring intra-personal, inter-personal and leadership skills; they consequently disregard the human aspect of enterprise (Hogan \& Warrenfeltz, 2003).

Emotional intelligence is fundamental to managers' understanding of the needs of others. The manager understands the multidimensional and interrelatedness of emotions and the responses that relate to specific emotions; as well as the need for strong communication skills and the ability to appreciate differing perspectives (Caruso, Mayer \& Salovey, 2002). The growing recognition of the significance of emotions at work, the changing role of the manager and empirical evidence linking emotional intelligence to performance outcomes, validates emotional intelligence as imperative in organizational life.

Today's diverse workforce reflects the evolution of the world and business environment. The lack of homogeneity in the workplace and the identification of the importance of inclusion, has prompted the practice of managing diversity (Downey, van der Werff, Thomas \& Plaut, 2015). The aim of managing diversity in an organization is to increase opportunities to achieve competitive advantage, by managing the similarities and differences amongst people. The essence of diversity management is reflected in Martin Luther King's landmark speech, 'I have a dream'. He envisioned that a time will come when people will only be judged by their character and capabilities, rather than their gender, age, colour of their skin, ethnic or cultural backgrounds and disabilities. The vision includes the hope that someday, all individuals irrespective of their differences will be able to 'sit together at the tables of sisterhood and brotherhood with open minds and not clenched fists' (Smith, 2009).

Scholars have made a case for diversity management competence in the healthcare sector (Gathers, 2003; Simms, 2013). This is because diversity management competence in healthcare is necessary for the adequate provision of services to the diverse customer base. The public healthcare workforce in Nigeria is relatively reflective of the Nigerian State, which is widely regarded as the most populous nation in Africa (The World Bank, 2013) and one of the most diverse countries in the world (Society for Human Resource Management, 2009). There are multiple facets of Nigeria's diversity which portends numerous positives for the workplace when managers possess the requisite skills to leverage on diversity. However, a lack of requisite competencies portends poor management of diversity, which could lead to many negative outcomes (Akinnusi, Sonubi \& Oyewunmi, 2017). Potentially, differences could result in members of the workforce having varying perceptions of each other, ranging from negative, neutral, and positive (Chattopadhyay, Tluchowska \& George, 2004). These variations in perception could impact on collaborations, interpersonal relations, and performance outcomes within the workplace.

A major challenge of the diverse workforce is the exclusion of certain individuals or groups based on differences such as, gender; age; ethnicity or cultural affiliation; religion; social class; disability etc. Within the Nigerian context, the public space is synonymous with the politics of exclusion (Alubo, 2011). Public healthcare in Nigeria is overwhelmed by many operational challenges (Oyewunmi \& Oyewunmi, 2014), hence the sustainability of the sector depends considerably on managers' competence in motivating the workforce towards the accomplishment of the sector's objectives. This study appraises the relationship between emotional intelligence and diversity management competence amongst managers in selected public healthcare institutions in Southwest Nigeria. The relevance of this study is apparent against the backdrop of the Nigerian State, given the multiple diversities which characterize the country and the attendant socio-dynamics. 


\section{Conceptual clarifications}

\subsection{Emotional intelligence}

The first appearance of the emotional intelligence construct was in a German publication by Leuner (1966). As an English word, the construct was used in the doctoral thesis of Payne (1985), who studied emotional experience and therapy. Salovey and Mayer (1990) were first to present a conceptual outline of aptitudes that constitute emotional intelligence. Goleman (1995) popularized the construct and conceptualized it as a universal characteristic possessed by all persons; a measurable spectrum of individual difference in which persons may be ranked on emotional scales.

Caruso and Salovey (2004) state that emotional intelligence involves being able to perceive, express, assimilate and make judgements with emotion. Emotional intelligence is a concept with multiple factors that incorporates different inter-connected emotional, personal, and social competencies, which enables individuals to adapt to the demands of the environment (Bar-On, 1997; Goleman, 1995). Gendron (2007) explains the concept as the ability to comprehend and apply emotions as a source of strength, creativity, and connection. Emotional intelligence is the consciousness and management of emotions, ability to influence the emotions of others with sensitivity, the sustenance of motivation, enthusiasm, and conscientiousness. In relation to the workplace, it is the skill to discern, communicate, comprehend, and coordinate emotions effectively at work.

There are variations in opinions as to what should constitute the domain of emotional intelligence (Zeidner, Matthews \& Roberts, 2004). For instance, the distinction amongst the ability, trait and mixed models of emotional intelligence have contributed to the debate on the legitimacy of the construct (Stough, Palmer, Gardener, Papageorgiou \& Redman, 2002). The theories of emotional intelligence are usually classified in two (2) forms; as an ability-based skill, as seen in definition of Mayer and Salovey (1997) and as a mixed model, which implies that emotional intelligence includes personality traits as seen in Goleman's (1995) definition. The variations in conceptualization is regarded as the 'ability model' versus 'mixed model' debate (Mayer, Caruso \& Salovey, 1999). Whilst some researchers have argued that there must be a singular, correct theoretical framework for emotional intelligence, others maintain that the divergence of theories serves the purpose of providing additional insights into the complex construct (Badenhorst \& Smith, 2007). Emmerling and Goleman (2003) opine that this is characteristic of theory building in any area of study, as theories emerge and differentiate; thereby providing robustness and not weakness.

Emotional intelligence has also been criticized as an unverified idea that is not useful to the comprehension of differences in people, beyond existing psychological dimensions (Woodruffe, 2001). Locke (2005) states that emotional intelligence is a void concept because it has become too broad, with too many variegated components and as such, is no longer an intelligible concept. Another criticism is that since emotional intelligence is closely related to intelligence and personality, being able to control these factors, equals emotional intelligence being useless (Decker, 2003). Despite these criticisms, emotional intelligence has reportedly indicated significant positive effects on several workplace outcomes.

This study adopts Goleman's (1995) model of emotional intelligence which consists of self-awareness, selfregulation, social awareness, and relationship management. Self-awareness as the capacity to recognize one's emotions and comprehend the effects of emotions on actions or behaviour (Goleman,1998). It is an individual's in-depth appreciation of his or her feelings, flaws, strengths, inclinations, and impulses (Goleman, Boyatzis \& Mckee, 2002). In the workplace, self-awareness refers to the practice of reflection and accurate appraisal of one's own behaviour and abilities. Self-regulation is a sense of positivity, initiative, dutifulness, and the ability to persevere in the pursuit of goals (Goleman, 1998). It is the capacity to react to constant environmental demands with the right emotions, in a way that is acceptable and suitable to allow spontaneous responses (Cole, Michel \& Teti, 1994). It may also be described as both an external and internal process, involving the observation, evaluation, and modification of emotional responses (Thompson, 1994). Human beings are constantly subjected to experiences that can stimulate various emotions. Unregulated emotional responses to such stimulations could hamper relationships within and outside the workplace (Zeman, Cassano, Perry-Parrish \& Stegall, 2006). Social awareness is a diverse and non- cognitive set of skills present in most social settings (Goleman, 2006). It is 
synonymous with the use of empathy, along social cognition, to go beyond verbal communication for a deeper assessment of intentions. Relationship management is the capacity to communicate, collaborate, and manage conflict in interpersonal relationships with others (Goleman, 1998). It refers to the facilitation of effective interaction and communication with others. According to Bradberry and Greaves (2005), relationship management employs the consciousness of individuals' emotions to manage interactions effectively.

\subsection{Diversity management competence}

Diversity has the power to evoke emotions within and outside the workplace. This is a major reason it has been a feature of management literature over the last twenty (20) years. Defining and conceptualizing diversity appears to be shrouded in ambiguities and has been regarded as an uneasy task (Nkomo \& Stewart, 2006). Originally, the term diversity comes from the Latin diversitas and the old French word diversité meaning difference, unique feature, oddness. In defining diversity, Carrell, Elbert, Hatfield, Grobler, Marx and Van der Schyf (1998) state that there are two (2) paradigms of diversity, i.e. primary and secondary. The primary paradigm of defining diversity refers to human differences such as age, gender, ethnicity, physical abilities. Another perspective argues that diversity is concerned with differences beyond the primary paradigm which include education, religion, and social class (Osland, Kolb \& Rubin, 2001). Diversity incorporates several demographic and socio-economic facets of the society, like the aging population, increase in immigration, the changed role of women at work, gender, and cultural disparities in the workplace (Drucker, 2007).

Workforce diversity connotes the variations and features that are attributable to individuals, like gender, age, ethnicity/culture, physical attributes, religion, economic and educational background. A diverse workforce comprises of persons with varying human attributes, as well as different cultures or ethnicities. An encompassing definition of workforce diversity includes differences in gender, age, race, culture, ethnicity, religion, affectionate orientation, etc. Workforce diversity may like likened to a doubled-edged sword because of its potential benefits and its possible challenges. It may portend increased creativity, innovation, and the probability that members of a diverse workforce may fail to identify with other persons with differing identities (Saxena, 2014). A diverse workforce is of great benefit to organizations seeking to maintain a competitive edge, particularly considering the dynamic business environment where flexibility and creativity are crucial to competitiveness. It can promote business opportunities, innovation, and corporate image. Also, organizations that employ a diverse workforce enjoy multiple resolutions to problems, because a diverse workforce contributes individual talents and ideas to problem solving processes. If the workforce feels at ease to communicate differing perspectives, it provides a wealth of ideas for the organization, resulting in better performance outcomes and profitability (D'Netto, Shen, Chelliah \& Monga, 2014).

A major challenge of workforce diversity is poor cohesiveness amongst employees. It may be difficult to cultivate cohesion because of differences in language, culture, and background of employees. The workforce may experience communication problems and misunderstandings. There could also be issues of mistrust and tension within the workplace because people generally prefer to associate with those that share the same background, values and beliefs that are similar to their own. This makes it important for organizations to effectively manage workplace diversity by ensuring the inclusion of all persons, fostering self-esteem and belongingness (Akinnusi et al., 2017).

Diversity management has become a popular term used in modern society and management practice. Many organizations around the world have developed policies that aim to promote and manage diversity. The birth of diversity management took place in the United States of America in the 1980's; and Roosevelt coined the term in 1983(Kelly \& Dobbin, 1998). Diversity management was driven by the increasing criticisms of Equal Employment Opportunity (EEO) and Affirmative Action (AA) initiatives which were in place in the 70's (Kandola \& Fuellerton, 1994).

The dominant understanding of diversity management highlighted the voluntary nature of the engagements, the inclusion of all differences, and corporate business interests as the driving force behind diversity initiatives. Generally, the motives for diversity management may be divided into external and internal possibilities. External 
possibilities of diversity management are new markets or new customer segments and social responsibility. Internal prospects include better performance, creativity, motivation, and employee retention (Reisinger, 2009). Globalization and the dynamic business environment makes diversity management an imperative for organization looking to thrive and survive in these contemporary times. The manager's role in diversity management is crucial. This is because roles and tasks of managers have changed to include, encouraging, inspiring and supporting the inclusion of all employees in spite of their backgrounds, to ensure the achievement of organizational goals. Managers must redefine the functions leadership and develop competencies that are requisite for managing workforce diversity.

Competence refers to an individually or inter-individually available collection of prerequisites for successful action in meaningful task domains (Weinert, 2001). Competencies are a combination of skills, knowledge, attitudes, personality traits and other individual characteristics that differentiate or impact on performance in a positive sense. Competencies are useful in linking education and job specifications (Boon \& van der Klink, 2002). The effective management of a diverse workforce requires specific managerial competencies conceptualized to include diversity awareness, diversity adaptability, diversity leveraging and inclusiveness. Diversity awareness is a person's ability to reflect on his/her own identity and recognize differences. It is an active, ongoing conscious process in which an individual recognizes similarities and differences amongst various social or cultural groups (Jeffreys, 2008). The awareness, respect, and value of differences in other people, makes it possible to genuinely value and appreciate diversity.

Diversity adaptability is an individual attribute that is necessary in managing differences (Pearlman \& Barney, 2000). It equates flexibility and openness to new ideas and diverse identities; understanding and balancing diverse views to achieve practical solutions; valuing change and acting effectively under pressure. Diversity leveraging involves the strategic engagement of diversity in achieving specific objectives (Davidson, 2011). When managers leverage on diversity, it becomes increasingly effortless. The organization begins to orient itself toward determining how differences can contribute to results in a sustainable sense. Inclusiveness refers to fair employment practices that eliminate bias and discrimination; norms and expectations that promote openness of individuals to be themselves. Managers must be competent in providing an inclusive workplace where all employees are appreciated and recognized regardless of differences, perceived as equals to other employees and encouraged to maintain their uniqueness (Bell, Özbilgin, Beauregard \& Sürgevil, 2011).

\section{Theoretical framework}

The theory of multiple intelligence proposes that individuals possess diverse abilities; hence, the concept of intelligence should not be stereotyped (Gardner, 1983). Emotional intelligence is based on Gardner's (1983) theory of multiple intelligences as it embodies the interpersonal and intrapersonal intelligences. Criticisms relating to the theory of multiple intelligences stem from the absence of psychometric support. Some of the advanced intelligences are not easily amenable to psychometric assessment, and there are methodological issues as some traditional assessments produce results that are biased against multiple intelligence theory (Almeida, Prieto, Ferreira, Bermejo, Ferrando \& Ferrándiz, 2010).

Social identity and social categorization (Tajfel \& Turner, 1986; Tajfel, Flament, Billing \& Bundy, 1971) are complimentary theories that explain the dynamics of intergroup interactions. They imply that organizations may or may not benefit from the relationship between individuals and social structures. This relationship may result in either an insider or outsider experience for the individual. Being part of a social group is a characteristic of human existence and this dynamic is apparent in the organizational context where individuals identify and categorize themselves in social groups. The social identity theory was advanced by Tajfel and Turner (1986) to explain the association between social structures and individual perception of identity. This connection determines membership in social groups and implies that people identify themselves with social groups per social comparisons that have are meaningful to them. Studies by Tajfel et al. (1971) found that when people identify with an in-group, they tend to see the positives of their in-group over other (out) groups. 
The social categorization theory refers to the cerebral process of comparison where individuals categorize themselves into groups based on similarities (Mor Barak, 2011). It is a cognitive instrument used to categorize individuals based on social environment, resulting in in-group or out-group biases and motivations (Tajfel et al., 1971). Tajfel and Turner (1986) state that people associate and collaborate with people that are like them. The social categorization theory advances the view that, status differences amongst social groups will result in stronger identification of individuals with their in-group and behavior that is in the interest of the in-group. Based on these theories, potential challenges for the diverse workplace include in-group favoritism and biases. These could impact negatively on behaviour and lead to outcomes such as, conflict, poor cohesion, poor communication, less cooperation amongst employees, job dissatisfaction and turnover intention.

The conscious competence theory suggests that individuals can be categorized in terms of their awareness of unawareness of their competence or incompetence (Robinson, 1974). The four (4) stages of competence include:

- Unconscious Incompetence: This suggests that an individual does not comprehend of recognize a deficit in skill. Without an awareness of incompetence, it might be difficult to assume the second stage of competence.

- Conscious Incompetence: The individual at this stage is aware of a competence deficit. This may result in the stimulation and willingness to acquire learning and competence.

- Conscious Competence: The individual is aware of his or her competence. Task execution however requires a measure of conscious concentration.

- Unconscious Competence: The individual's competence has become second nature and can be performed with ease and no pressure.

A relevant theory associated with the Theory of Conscious Competence is the Dunning- Kruger Effect (Kruger \& Dunning, 1999). This refers to a form of cognitive bias where individuals who are relatively unskilled, incompetent or inept, have a form of delusional or illusory superiority, because of wrong assessment of their abilities. Kruger and Dunning (1999) state that highly skilled individuals may underestimate their relative competence. The Dunning-Kruger Effect resonates the thought of Confucius that 'real knowledge is to know the extent of one's ignorance' and the opinion of Charles Darwin that 'ignorance can frequently beget confidence than does knowledge'. The theory of conscious competence and the Dunning-Kruger Effect can be applied to emotional intelligence and diversity management competence. Managers are either at the stage of unconscious incompetence, conscious incompetence, conscious competence, or unconscious competence. The first two stages have negative implications for the workplace. Managers who are unconsciously incompetent will find it difficult to motivate employees to achieve set objectives, may be egoistical, unamenable to change and unable to effectively manage a diverse workforce. Individuals in this category are unaware of their ineptitude and will consistently do things the wrong way because of the unawareness of incompetence. Managers who are conscious of their incompetence and are unwilling to acquire requisite skills and competencies will find it difficult to manage diverse and competent employees. The challenge however is getting managers who are unconsciously incompetent to become self-aware and acquire competencies, and managers who are consciously incompetent to acquire competencies. In relation with workforce diversity, many individuals have set biases and stereotypes, and may not be open to perspectives and competencies that oppose their convictions.

\section{Hypotheses formulation}

Studies which clearly demonstrate the relationship between managers' emotional intelligence and diversity management competence are limited. Magoshi and Chang (2009) studied the effects of diversity management on employee commitment in Japan and Korea, where the workforce is highly homogenous. The study sampled five hundred and eighty-two (582) respondents from both countries and the results indicate that diversity management strategies have positive effects on employees' commitment to their organizations. Although there is a popular perception that individuals prefer homogenous groups, this might not necessarily translate to 
performance or effectiveness in the workplace. When heterogonous groups are properly managed, they have great potential for productivity. Using a sample of ninety-eight executive MBA students, Lillis and Krzystofiak (2007) found that group emotional intelligence indicates positive performance outcomes in heterogeneous groups than in homogenous groups.

As international corporations operate in a dynamic environment defined by multi-cultural differences, Reilly and Karounos (2009) examined the connection between emotional intelligence and cross-cultural leadership effectiveness. Being a cross-cultural study, four cultural clusters were sampled; Anglo, Latin European; Eastern European; and South Asia. Mid-to-upper-level international sales managers were surveyed, and results showed that emotional intelligence is more esteemed compared to cognitive abilities. The study supported earlier findings that transformational leadership style is favored across cultures. The results also suggested that emotional intelligence is crucial to global management. The need to establish strong relationships with cross-cultural customers and employees is an example of social awareness and relationship management.

Saberi (2012) studied the role of emotional intelligence in promoting inter-cultural sensitivity using a sample of respondents from nine countries. The findings indicated that emotional intelligence abilities enhance intercultural sensitivity in the process of inter-cultural adaptation. Kamps and Engelbrecht (2011) found a positive relationship between emotional intelligence and the appreciation of differences. A study on the effect of age diversity on the Nigerian workforce as conducted by Owoyemi, Elegbede and Gbajumo-Sheriff (2011) expressed the importance of harnessing the potential each employee towards organizational performance. The findings of their study reveal the importance of a balanced workforce composition as well as the need to develop models to promote compatibility and cooperation among diverse age groups in the workplace.

Management research has been integrative in establishing the relationship amongst emotional intelligence, leadership effectiveness, employee and organizational performance and so on (e.g. Batool, 2013; Popoola \& Zaid, 2015; Oyewunmi, Oyewunmi, Ojo \& Oludayo, 2015). However, the increasing heterogeneity of the global workforce makes it imperative to clearly ascertain the relationship between emotional intelligence and diversity management competence. Therefore, this study hypothesized that:

H1: motional intelligence contributes significantly to diversity management competence.

H2: Gender and age moderate the relationship between emotional intelligence and diversity management competence.

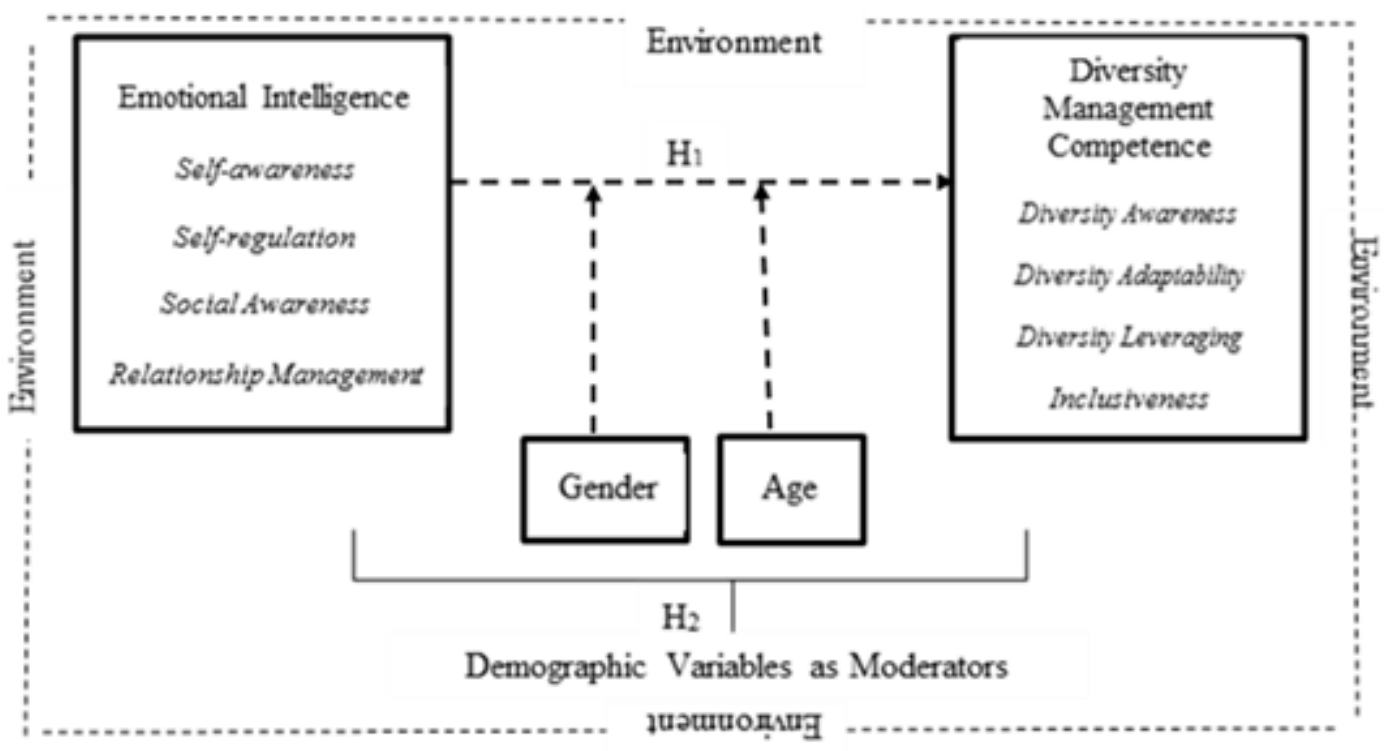

Figure 1. Schematic Model 


\section{Methods}

\subsection{Participants}

The participants for the study consisted of three hundred and sixty (360) professional healthcare practitioners in the managerial cadre. The sample was limited to the managerial cadre of employees because they are either currently managing diverse teams or have managed diverse teams in the past. This set of employees possess a reasonable amount of insight regarding the intricacies of managing differences and similarities in the workplace. The study covered selected public healthcare institutions in the four (4) oldest States in Southwestern Nigeria. Government-owned hospitals are at the tertiary level of the national care system. Hence, they have a broader scope of operations, teaching and research facilities.

\subsection{Research instrument}

The research instrument contained items from the Emotional Intelligence Scale, designed by Schutte et al. (1998). The 33-item measure is structured to appraise an individual's perceptions of the extent to which she/he can recognize, comprehend, and manage emotions in themselves and in other people. Respondents for this study were asked to rate themselves on these emotional intelligence traits. Schutte et al. (1998) report a satisfactory internal consistency reliability ( $\mathrm{r}=0.87$ to .90$)$ and adequate test-retest reliability $(\mathrm{r}=0.78)$. Additional items were added to the questionnaire to determine diversity awareness, diversity adaptability, diversity leveraging (Davidson, 2011) and inclusiveness (Hollander, Park, Boyd, Elman \& Ignagni, 2008). Other items in the research instrument targeted the demographic profiles of espondents. The internal consistency of the research instrument is found at Cronbach's Alpha value of .820, which indicates a high level of internal consistency.

\subsection{Data analysis}

Collected data were coded and the moderation statistical technique was deployed to measure the interaction effect of demographic variables on the tested relationships, through the hierarchical regression model. Stata 12.0 was used to generate the structural equation model for the relationships tested.

\section{Results}

\begin{tabular}{|c|c|c|c|}
\hline & & $\mathbf{N}$ & $\%$ \\
\hline \multirow[t]{2}{*}{ Gender } & M & 175 & 49 \\
\hline & $\mathrm{F}$ & 185 & 51 \\
\hline \multirow[t]{3}{*}{ Age } & $31-40$ & 145 & 40 \\
\hline & $41-50$ & 152 & 42 \\
\hline & Above 50 & 63 & 18 \\
\hline \multirow[t]{5}{*}{ Marital Status } & Single & 32 & 9 \\
\hline & Married & 217 & 60.2 \\
\hline & Divorced & 84 & 23.3 \\
\hline & Separated & 16 & 4.4 \\
\hline & Widowed & 11 & 3.1 \\
\hline \multirow[t]{4}{*}{ Highest Educational Qualification } & Diploma & 3 & 0.8 \\
\hline & $1^{\text {st }}$ Degree (Bachelors) & 217 & 60 \\
\hline & $2^{\text {nd }}$ Degree (Masters) & 126 & 35 \\
\hline & $3^{\text {rd }}$ Degree (Ph.D.) & 14 & 4 \\
\hline \multirow[t]{4}{*}{ Work Experience } & $1-5$ years & 12 & 3 \\
\hline & $6-10$ years & 130 & 36 \\
\hline & $11-15$ years & 97 & 27 \\
\hline & 15years and above & 121 & 34 \\
\hline
\end{tabular}




\begin{tabular}{|l|l|r|r|}
\cline { 3 - 4 } \multicolumn{2}{|c|}{ Profession } & N & $\%$ \\
\cline { 2 - 4 } & Medical Doctors & 62 & 17 \\
\cline { 2 - 4 } & Nurses & 165 & 46 \\
\cline { 2 - 4 } & Administrators & 23 & 20 \\
\cline { 2 - 4 } & Pharmacists & 39 & 11 \\
\cline { 2 - 4 } & Others & 23 & 11 \\
\hline
\end{tabular}

Table 1. Demographic Characteristics of Respondents

To conduct the analysis showing the level of influence of independent variables on the dependent variables, one of the main assumptions to be established is that the data collected are normally distributed, hence the need to standardize (or centralize as in some text). The standardized variables were used for the analysis. The influence of emotional intelligence on diversity management competence is significant, with emotional intelligence explaining $15 \%$ of the variation in diversity management, with $\beta$-coefficient of 0.387 and $p$-value of 0.000 . The relationship was not moderated by gender but was significantly moderated by age. To understand the influence of emotional intelligence on diversity management competence, the constructs were further composed to shows the influence that each of the sub-constructs of emotional intelligence has on sub-constructs of diversity management competence. The structural equation model that was tested is shown in Figure 2.

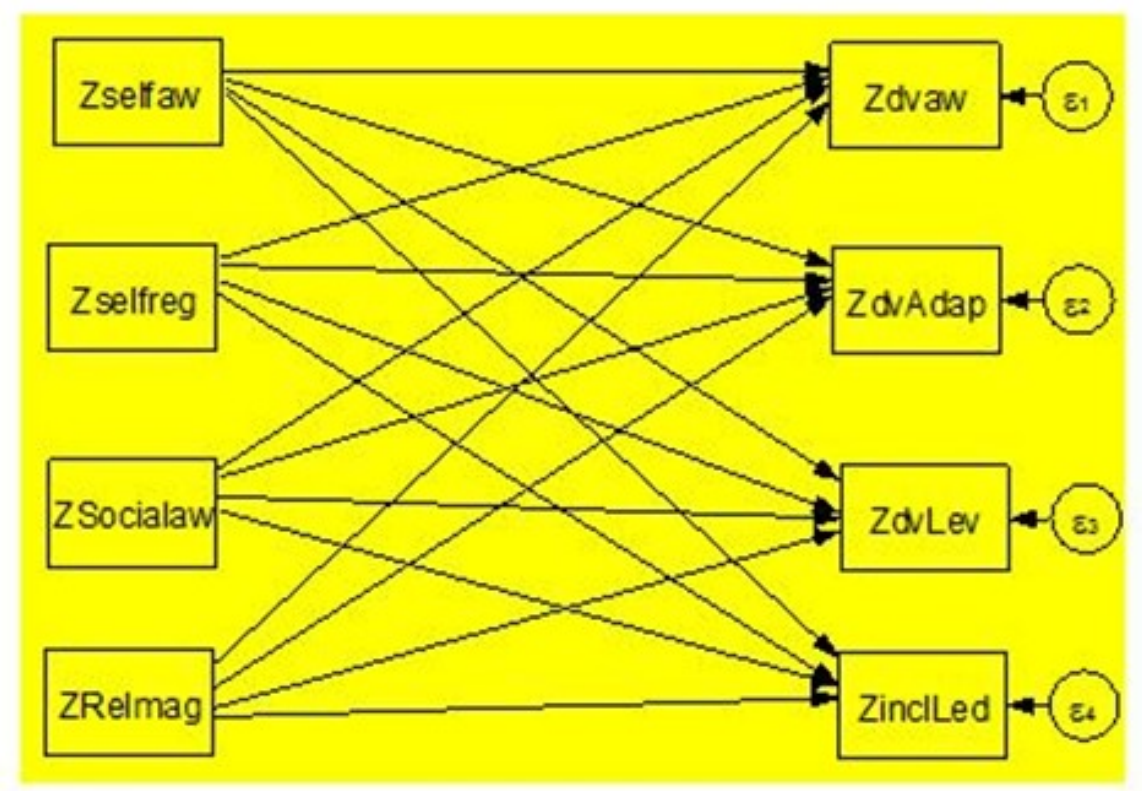

Figure 2. Structural Equation Model of Sub-constructs

The results shown in Table 1 indicate that relationship management and social awareness significantly influence diversity awareness. From the regression analysis, it shows that relationship management has a beta coefficient value of 0.245 with p-value of 0.000 while social awareness has coefficient of 0.286 with p-value of 0.000 . The model of all four independent variables (i.e. relationship management, social awareness, self-awareness, and selfregulation) explained $14.6 \%$ of the variation in the diversity awareness, with p-value of 0.000 , indicating that the model is significant.

Using relationship management, social awareness, self-awareness, and self-regulation as independent variables that influence diversity adaptability, the models shows that the independent variables explained $17.9 \%$ of the variation in diversity adaptability. The model is significant, having a p-value of 0.000 . Only the influence of social awareness was significant on the dependent variable, having a coefficient of 0.424 with p-value of 0.000 .The influence of relationship management and self-regulation were significant on diversity leveraging, each having coefficient of 0.178 and 0.141 respectively, with p-value of 0.001 and 0.012 respectively. The model (with 
relationship management, social awareness, self-awareness, and self-regulation as independent variables) explains $7.9 \%$ of the variation observed in the dependent variable and is significant with p-value of 0.000 .

Out of the four independent variables, relationship management, social awareness and self- regulation significantly influence inclusiveness; each has beta coefficients of $0.184,0.257$ and 0.131 respectively. The pvalue for these three variables are $0.000,0.000$ and 0.014 respectively. The entire model explains $16.2 \%$ of variation on dependent variables and its significant with p-value of 0.000 .

\begin{tabular}{|c|c|c|c|c|c|c|c|}
\hline Dependent & Independent & $\begin{array}{l}\text { Beta } \\
\text { coefficients }\end{array}$ & $\begin{array}{l}\text { P-value of } \\
\text { Beta } \\
\text { coefficients }\end{array}$ & Remark & R-sq & $\begin{array}{l}\text { Durbin- } \\
\text { Watson }\end{array}$ & $\begin{array}{l}\mathrm{p} \text {-value } \\
\text { (of model) }\end{array}$ \\
\hline \multirow{4}{*}{$\begin{array}{l}\text { Diversity } \\
\text { Awareness }\end{array}$} & $\begin{array}{l}\text { Relationship } \\
\text { management }\end{array}$ & 0.245 & 0.000 & Significant & \multirow{4}{*}{0.146} & \multirow{4}{*}{1.840} & \multirow{4}{*}{0.000} \\
\hline & $\begin{array}{l}\text { Social } \\
\text { Awareness }\end{array}$ & 0.286 & 0.000 & Significant & & & \\
\hline & Self-awareness & 0.026 & 0.596 & $\begin{array}{l}\text { Not } \\
\text { Significant }\end{array}$ & & & \\
\hline & Self-regulation & 0.032 & 0.550 & $\begin{array}{l}\text { Not } \\
\text { Significant }\end{array}$ & & & \\
\hline \multirow{4}{*}{$\begin{array}{l}\text { Diversity } \\
\text { Adaptability }\end{array}$} & $\begin{array}{l}\text { Relationship } \\
\text { management }\end{array}$ & -0.021 & 0.680 & $\begin{array}{l}\text { Not } \\
\text { Significant }\end{array}$ & \multirow{4}{*}{0.179} & \multirow{4}{*}{1.852} & \multirow{4}{*}{0.000} \\
\hline & $\begin{array}{l}\text { Social } \\
\text { Awareness }\end{array}$ & 0.424 & 0.000 & Significant & & & \\
\hline & Self-awareness & -0.035 & 0.467 & $\begin{array}{l}\text { Not } \\
\text { Significant }\end{array}$ & & & \\
\hline & Self-regulation & 0.000 & 0.998 & $\begin{array}{l}\text { Not } \\
\text { Significant }\end{array}$ & & & \\
\hline \multirow{4}{*}{$\begin{array}{l}\text { Diversity } \\
\text { Leveraging }\end{array}$} & $\begin{array}{l}\text { Relationship } \\
\text { management }\end{array}$ & 0.178 & 0.001 & Significant & \multirow{4}{*}{0.079} & \multirow{4}{*}{2.129} & \multirow{4}{*}{0.000} \\
\hline & $\begin{array}{l}\text { Social } \\
\text { Awareness }\end{array}$ & 0.076 & 0.153 & $\begin{array}{l}\text { Not } \\
\text { Significant }\end{array}$ & & & \\
\hline & Self-awareness & -0.016 & 0.753 & $\begin{array}{l}\text { Not } \\
\text { Significant }\end{array}$ & & & \\
\hline & Self-regulation & 0.141 & 0.012 & Significant & & & \\
\hline \multirow{4}{*}{ Inclusiveness } & $\begin{array}{l}\text { Relationship } \\
\text { management }\end{array}$ & 0.184 & 0.000 & Significant & \multirow{4}{*}{0.162} & \multirow{4}{*}{1.700} & \multirow{4}{*}{0.000} \\
\hline & $\begin{array}{l}\text { Social } \\
\text { Awareness }\end{array}$ & 0.257 & 0.000 & Significant & & & \\
\hline & Self-awareness & 0.085 & 0.084 & $\begin{array}{l}\text { Not } \\
\text { Significant }\end{array}$ & & & \\
\hline & Self-regulation & 0.131 & 0.014 & Significant & & & \\
\hline
\end{tabular}

Table 2. Regression Analyses

The relationships that were moderated are shown in Table 2, with the Beta coefficient and p-value of the moderators.

- The influence of emotional intelligence on diversity management competence was moderated by age $(\beta=0.103 ; \mathrm{p}$-value $=0.042)$, the relationship is significantly affected by ages between $41-50$ years.

- The influence of social awareness on diversity awareness was moderated by gender $(\beta=-0.144$; $\mathrm{p}$-value 0.005), the relationship is significantly affected in the male gender.

- The influence of self-regulation on diversity awareness was moderated by gender $(\beta=-0.137$; $\mathrm{p}$-value $=$ 0.008), the relationship is significantly affected in the male gender. 
- The influence of relationship management on diversity leveraging was moderated by gender $(\beta=-0.117$; p-value $=0.027$ ), the relationship is significantly affected in the female gender.

- The influence of relationship management on inclusiveness was moderated by gender $(\beta=-0.122$; $\mathrm{p}$ value $=0.022)$, the relationship is significantly affected in the male gender.

\begin{tabular}{|c|c|c|c|c|c|c|c|c|}
\hline $\begin{array}{l}\text { Dependent } \\
\text { variable }\end{array}$ & $\begin{array}{l}\text { Independent } \\
\text { variable }\end{array}$ & moderators & $\begin{array}{l}\text { r-sq (with } \\
\text { independent } \\
\text { variable) }\end{array}$ & $\begin{array}{l}\text { r-sq (with } \\
\text { moderators) }\end{array}$ & $\begin{array}{l}\text { Beta } \\
\text { coefficient } \\
\text { of } \\
\text { moderator }\end{array}$ & $\begin{array}{l}\mathrm{p} \text {-value of } \\
\text { moderator }\end{array}$ & remarks & $\begin{array}{l}\text { Significant } \\
\text { group in } \\
\text { moderator }\end{array}$ \\
\hline \begin{tabular}{|l|} 
Diversity \\
Management
\end{tabular} & $\begin{array}{l}\text { Emotional } \\
\text { intelligence, } \\
\text { Gender }\end{array}$ & Emotional*Gender & 0.153 & 0.151 & -0.010 & 0.841 & $\begin{array}{l}\text { Not } \\
\text { significant }\end{array}$ & \\
\hline \begin{tabular}{|l} 
Diversity \\
management
\end{tabular} & $\begin{array}{l}\text { Emotional } \\
\text { intelligence, } \\
\text { Age }\end{array}$ & Emotional*Age & 0.167 & 0.175 & 0.103 & 0.042 & Significant & $\begin{array}{l}\text { Between } 41 \\
-50 \text { years }\end{array}$ \\
\hline \begin{tabular}{|l|} 
Diversity \\
awareness
\end{tabular} & \begin{tabular}{|l|} 
Social \\
Awareness, Age
\end{tabular} & Social awareness*Age & 0.098 & 0.099 & 0.034 & 0.514 & $\begin{array}{l}\text { Not } \\
\text { significant }\end{array}$ & \\
\hline $\begin{array}{l}\text { Diversity } \\
\text { awareness }\end{array}$ & \begin{tabular}{|l|} 
Social \\
awareness, \\
Gender
\end{tabular} & $\begin{array}{l}\text { Social } \\
\text { awareness*Gender }\end{array}$ & 0.098 & 0.118 & -0.144 & 0.005 & Significant & Male \\
\hline \begin{tabular}{|l|} 
Diversity \\
awareness
\end{tabular} & $\begin{array}{l}\text { Self-regulation, } \\
\text { Age }\end{array}$ & Self-regulation*Age & 0.046 & 0.047 & -0.034 & 0.525 & \begin{tabular}{|l|} 
Not \\
significant
\end{tabular} & \\
\hline $\begin{array}{l}\text { Diversity } \\
\text { awareness }\end{array}$ & $\begin{array}{l}\text { Self- regulation, } \\
\text { Gender }\end{array}$ & $\begin{array}{l}\text { Self- } \\
\text { regulation*Gender }\end{array}$ & 0.050 & 0.069 & -0.137 & 0.008 & Significant & Male \\
\hline $\begin{array}{l}\text { Diversity } \\
\text { adaptability }\end{array}$ & \begin{tabular}{|l|}
$\begin{array}{l}\text { Social } \\
\text { awareness, Age }\end{array}$ \\
\end{tabular} & Social awareness*age & 0.178 & 0.183 & 0.072 & 0.143 & $\begin{array}{l}\text { Not } \\
\text { significant }\end{array}$ & \\
\hline $\begin{array}{l}\text { Diversity } \\
\text { adaptability }\end{array}$ & $\begin{array}{l}\text { Social } \\
\text { awareness, } \\
\text { Gender }\end{array}$ & $\begin{array}{l}\text { Social } \\
\text { awareness } * \text { Gender }\end{array}$ & 0.177 & 0.177 & -0.021 & 0.661 & $\begin{array}{l}\text { Not } \\
\text { significant }\end{array}$ & \\
\hline $\begin{array}{l}\text { Diversity } \\
\text { leveraging }\end{array}$ & $\begin{array}{l}\text { Relationship } \\
\text { management, } \\
\text { Age }\end{array}$ & $\begin{array}{l}\text { Relationship } \\
\text { management*Age }\end{array}$ & 0.066 & 0.067 & -0.024 & 0.655 & $\begin{array}{l}\text { Not } \\
\text { significant }\end{array}$ & \\
\hline $\begin{array}{l}\text { Diversity } \\
\text { leveraging }\end{array}$ & $\begin{array}{l}\text { Relationship } \\
\text { management, } \\
\text { Gender } \\
\end{array}$ & $\begin{array}{l}\text { Relationship } \\
\text { management*Gender }\end{array}$ & 0.063 & 0.076 & -0.117 & 0.027 & Significant & Female \\
\hline \begin{tabular}{|l|} 
Diversity \\
leveraging
\end{tabular} & $\begin{array}{l}\text { Self- regulation, } \\
\text { Age }\end{array}$ & Self- regulation*Age & 0.067 & 0.070 & -0.064 & 0.241 & $\begin{array}{l}\text { Not } \\
\text { significant }\end{array}$ & \\
\hline \begin{tabular}{|l|} 
Diversity \\
leveraging
\end{tabular} & $\begin{array}{l}\text { Self- regulation, } \\
\text { Gender }\end{array}$ & $\begin{array}{l}\text { Self- } \\
\text { regulation*Gender }\end{array}$ & 0.057 & 0.059 & 0.037 & 0.471 & $\begin{array}{l}\text { Not } \\
\text { significant }\end{array}$ & \\
\hline Inclusiveness & $\begin{array}{l}\text { Relationship } \\
\text { management }\end{array}$ & $\begin{array}{l}\text { Relationship } \\
\text { management*Age }\end{array}$ & 0.078 & 0.081 & 0.060 & 0.258 & $\begin{array}{l}\text { Not } \\
\text { significant }\end{array}$ & \\
\hline Inclusiveness & $\begin{array}{l}\text { Relationship } \\
\text { management }\end{array}$ & $\begin{array}{l}\text { Relationship } \\
\text { management*Gender }\end{array}$ & 0.052 & 0.066 & -0.122 & 0.022 & Significant & Male \\
\hline Inclusiveness & \begin{tabular}{|l|}
$\begin{array}{l}\text { Social } \\
\text { awareness, Age }\end{array}$ \\
\end{tabular} & Social awareness*Age & 0.114 & 0.118 & 0.065 & 0.206 & $\begin{array}{l}\text { Not } \\
\text { significant }\end{array}$ & \\
\hline Inclusiveness & $\begin{array}{l}\text { Social } \\
\text { awareness, } \\
\text { Gender }\end{array}$ & $\begin{array}{l}\text { Social } \\
\text { awareness*Gender }\end{array}$ & 0.089 & 0.095 & -0.078 & 0.130 & $\begin{array}{l}\text { Not } \\
\text { significant }\end{array}$ & \\
\hline Inclusiveness & $\begin{array}{l}\text { Self- regulation, } \\
\text { Age }\end{array}$ & Self- regulation*Age & 0.099 & 0.100 & 0.036 & 0.511 & $\begin{array}{l}\text { Not } \\
\text { significant }\end{array}$ & \\
\hline Inclusiveness & $\begin{array}{l}\text { Self- regulation, } \\
\text { Gender }\end{array}$ & $\begin{array}{l}\text { Self- } \\
\text { regulation*Gender }\end{array}$ & 0.067 & 0.067 & -0.026 & 0.615 & $\begin{array}{l}\text { Not } \\
\text { significant }\end{array}$ & \\
\hline
\end{tabular}

Table 3. Results of Moderated Relationships

\section{Discussion of findings}

From the results, there is a significant relationship between emotional intelligence and diversity management competence. Just as emotional intelligence is a critical factor for performance on multiple levels, it is also a crucial factor for managing a diverse workforce. The result of the model hypothesis resonates with the study conducted by Bourdon (2010), where a significant relationship was established between emotional intelligence and diversity receptiveness. The finding is also synonymous with the results of Kamps and Engelbrecht (2010), who found a strong relationship between emotional intelligence and the valuing of individual differences. 
Relatively, human beings perceive a sense of insecurity or lack of trust amidst people who are different from them in terms of, ethnicity, nationality, gender, age, religion, social class. Therefore, diversity in the workplace has the potential to trigger emotional reactions which can be managed using emotional intelligence.

To expressly leverage on diversity, individual managers must utilize emotional intelligence to facilitate relationships. Managerial deficit in emotional intelligence is tantamount to poor management of diversity, which could potentially lead to, poor interpersonal relations, discrimination, employee turnover, absenteeism, loss of organizational repute, inability to attract quality employees and poor performance outcomes. For managers, the benefits of emotional intelligence in managing diversity potentially include, increased self-confidence, harmonious relationships and decreased stress (Osibanjo, Salau, Falola \& Oyewunmi, 2016). For the organization potential benefits include, increased teamwork and collaboration, enhanced commitment, motivation, decreased conflict, positive attitude, decreased turnover, creativity, and innovation from diverse perspectives.

A major implication of the finding is the importance of interventionist research in the areas of emotional intelligence and diversity management competence. That is, given the relationship that exists between emotional intelligence and diversity management competence, the focus of research and the workplace should be how to develop these competencies in the workforce. Without doubt, competencies can be developed. The fundamental issue is ascertaining the model, method, or approach to achieve this, particularly within the Nigerian context where many entrenched convictions and deep-seated biases exist. Disposition to diversity transcends education, status, or exposure, as many people hold on to biases which are driven by social learning and personal motives. The development of emotional intelligence will appeal to the base of human psyche; it is a practical and strategic approach to enhancing diversity management competence without stoking the emotions and negativities that are usually attributable to diversity and diversity management.

The relative moderating effect of age and gender on emotional intelligence and diversity management competence should serve as motivation for the development of emotional intelligence. This would provide a platform for individual stakeholders to learn emotional intelligence and unlearn negative perceptions or stereotypes relating to diversity. The implications of the findings against the backdrop of the peculiarities of the Nigerian context reinforces the need to develop self-awareness, self-regulation; social awareness and relationship management. The development of these competencies will engender diversity management competence.

\section{Recommendations and suggestions for further studies}

Government-owned institutions are established to cater for the generality of the society. This objective can only be fully realized if the employees of such organizations possess requisite competencies. It is recommended that the management of these institutions be fully committed to continuous capacity building. Also important is the objective appraisal and integration of competencies, which will impact on managerial development and client experience. A contrary situation will limit organizational performance and sustainability. Managers must champion the re-engineering of organizational culture to promote equal opportunities, inclusion and diversity leveraging.

Recommendations for the academia entails ensuring the dissemination of applicable theories and practices related to the themes of emotional intelligence and diversity management competence. A composite aggregation of these interrelated concepts is imperative to birth a new breed of managers. Therefore, there is a need for investments in knowledge base that will positively impact work contexts. For instance, university curricular should be reappraised to accommodate emotional intelligence to facilitate the production of total graduates that can manage the complexities of the diverse workforce (Oyewunmi, Osibanjo \& Adeniji, 2016). Graduate business schools should also design practical courses aimed at developing the emotional in telligence quotient of students. The academia must constantly engage the industry to gain a fuller appreciation of unfolding realities in the diverse workplace.

As the relevance of emotional intelligence to organizational life is not in doubt, there is need for interventionist research on developing emotional intelligence across different contexts. Interventionist research particularly in the healthcare sector can be centred on preparation for change, training and capacity building, knowledge 
transfer and evaluative processes. This study was limited to public healthcare institutions; further studies may be conducted across multiple sectors and workplace contexts. A longitudinal study of this nature will aid further inferences and provide a richer pool of data for generalizations. Researchers can also adopt the qualitative or mixed method approaches to gather more insights on the challenges and opportunities of the diverse workplace.

\section{Declaration of Conflicting Interests}

The author declared no potential conflicts of interest with respect to the research, authorship, and/or publication of this article.

\section{Funding}

The author acknowledges the support of Covenant University Centre for Research, Innovation and Discovery (CUCRID).

\section{References}

Akinnusi, D. M., Sonubi, O., \& Oyewunmi, A.E. (2017). Fostering effective workforce diversity management in Nigerian organizations: The challenge of Human Resource Management. International Review of Management and Marketing, 7(2), 108-116.

Almeida, L.S., Prieto, M.D., Ferreira, A.I., Bermejo, M.R., Ferrando, M., \& Ferrándiz, C. (2010). Intelligence assessment: Gardner multiple intelligence theory as an alternative. Learning and Individual Differences, 20, 225-230. https://doi.org/10.1016/j.lindif.2009.12.010

Alubo, O. (2011). The public space in Nigeria: Politics of power, gender and exclusion. Africa Development, XXXVI(1), 75-95.

Ashkanasy, N.M., Hartel, C.E.J., \& Daus, C.S. (2002). Diversity and emotion: The new frontiers in organizational research. The Journal of Management, 28(3), 307-338. https://doi.org/10.1177/014920630202800304

Badenhorst, A., \& Smith, D. (2007). Misconceptions about emotional intelligence: Deploying emotional intelligence in one's life dimensions. South African Journal of Human Resource Management, 5(3), 1-10. https://doi.org/10.4102/sajhrm.v5i3.146

Bar-On, R. (1997). The Emotional Intelligence Inventory (EQ-I): Technical Manual. Toronto: Canada: Multi-Health Systems.

Batool, B.F. (2013). Emotional intelligence and effective leadership. Journal of Business Studies Quarterly, 4(3), 84-94.

Bell, M.P., Özbilgin, M.F., Beauregard, T.A., \& Sürgevil, O. (2011). Voice, silence, and diversity in 21st century organizations: Strategies for inclusion of gay, lesbian, bisexual, and transgender employees. Human Resource Management, 50(1), 131-146. https://doi.org/10.1002/hrm.20401

Boon, J., \& van der Klink, M. (2002). Competencies: The triumph of a fuzzy concept. Academy of Human Resource Development Annual Conference, Honolulu, HA, 27 February - 3 March, in: Proceedings, 1, 327-334.

Bourdon, J.A. (2010). Emotional intelligence and diversity receptiveness of leaders in federal government: A correlation study. Unpublished thesis, University of Phoenix.

Bradberry, T., \& Greaves, J. (2005). The emotional intelligence quick book: How to put your EQ to work. New York: Simon and Schuster.

Carrell, M.R., Elbert, N.F., Hatfield, R.D., Grobler, P.A., Marx, M., \& van der Schyf, S. (1998). Human resource management in South Africa. Cape Town: Pearson Education.

Caruso, D.R., Mayer, J.D., \& Salovey, P. (2002). Relation of an ability measure of emotional intelligence to personality. Journal of Personality Assessment, 79(2), 306-320. https://doi.org/10.1207/S15327752JPA7902_12

Caruso, D.R., \& Salovey, P. (2004). The emotional intelligent manager. San Francisco: Jossey-Bass. 
Chattopadhyay, P., Tluchowska, M., \& George, E. (2004). Identifying the in-group: A closer look at the influence of demographic dissimilarity on employee social identity. Academy of Management Review, 29(2), 180-202. https://doi.org/10.5465/amr.2004.12736071

Cole, P., Michel, M., \& Teti, L. (1994). The development of emotion regulation and dysregulation: A clinical perspective. Monographs of the Society for Research in Child Development, 59, 73-100. https://doi.org/10.2307/1166139

D’Netto, B., Shen, J., Chelliah, J., \& Monga, M. (2014). Human resource diversity management practices in the Australian manufacturing sector. The International Journal of Human Resources, 25(9), 1243-1266. https://doi.org/10.1080/09585192.2013.826714

Davidson, M.N. (2011). The end of diversity as we know it: Why diversity efforts fail and how leveraging difference can succeed. San Francisco: Berrett-Koehler.

Decker, T. (2003). Is emotional intelligence a viable concept?. Academy of Management Review, 28(2), 433-440.

Downey, S.N., van der Werff, L., Thomas, K.M., \& Plaut, V.C. (2015). The role of diversity practices and inclusion in promoting trust and employee engagement. Journal of Applied Social Psychology, 45, 35-44. https://doi.org/10.1111/jasp.12273

Drucker, P.F. (2007). The practice of management. New York: Routledge.

Emmerling, R.J., \& Goleman, D. (2003). Emotional Intelligence: Issues and common understanding. Issues and Recent Developments in Emotional Intelligence, 1(1). Available at: www.eiconsortium.org

Gardner, H. (1983). Frames of mind: The theory of multiple intelligences. New York: Basic Books.

Gathers, D. (2003). Diversity management: An imperative for healthcare organizations. Hospital Topics, 81(3), 14-20. https://doi.org/10.1080/00185860309598023

Gendron, B. (2007). Emotional capital: a crucial capital for a citizenship society with personal, social and economic returns. Citizenship education in society: Proceedings of the ninth conference of the children's identity in Europe thematic network, London.

Goleman, D. (1995). Emotional intelligence. New York: Bantam Books.

Goleman, D. (1998). Working with emotional intelligence. London: Bloomsbury.

Goleman, D. (2006). Social intelligence: The new science of human relationships. New York: Bantam Books.

Goleman, D., Boyatzis, R., \& McKee, A. (2002). The new leaders: Transforming the art of leadership into the science of results. London: Little Brown.

Hogan, R., \& Warrenfeltz, R. (2003). Educating the modern manager. Academy of Management Learning and Education, 2(1), 74-84. https://doi.org/10.5465/amle.2003.9324043

Hollander, E.P., Park, J., Boyd, B., Elman, B., \& Ignagni, M.E. (2008). Inclusive leadership and leader-follower relations: Concepts, research, and applications. Baruch College and Graduate Centre, City University of New York (CUNY).

Jeffreys, M. (2008). Dynamics of diversity: Becoming better nurses through diversity awareness. NSNA Imprint, 38-41.

Kamps, J.M., \& Engelbrecht A.S. (2011). The influence of emotional intelligence on diversity complexity cognition and the attitude towards diversity. South African Journal of Business Management, 42(3), 37.

Kandola, R., \& Fullerton, J. (1994). Diversity: More than just an empty slogan. Personnel Management, November, 45-50.

Kelly, E., \& Dobbin, F. (1998): How affirmative action became diversity management: Employer response to anti-discrimination law, 1961-1996. American Behavioural Scientist, 41, 960-984.

https://doi.org/10.1177/0002764298041007008

Kruger, J., \& Dunning, D. (1999). Unskilled and unaware of it: How difficulties in recognizing one's competence leads to inflated self-assessments. Journal of Personality and Psychology, 77(6), 1121-1134.

https://doi.org/10.1037/0022-3514.77.6.1121 
Leuner, B. (1966). Emotionale intelligenz und emanzipation (Emotional intelligence and emancipation). Praxis der Kinderpsychologie und Kinderpsycbiatry, 15, 196-203.

Lillis, M.P., \& Krzystofiak, F.J. (2007). Emotional intelligence, diversity, and group performance: The effect of team composition on executive education program outcomes. Journal of Executive Education, 6(1), 41-54.

Locke, E.A. (2005). Why emotional intelligence is an invalid concept. Journal of Organizational Behavior, 26, 425-431. https://doi.org/10.1002/job.318

Magoshi, E., \& Chang, E. (2009). Diversity management and the effects on employees' organizational commitment: Evidence from Japan and Korea. Journal of World Business, 44, 31-40. https://doi.org/10.1016/j.jwb.2008.03.018

Mayer, J.D., \& Salovey, P. (1997). What is emotional intelligence? New York: Basic Books.

Mayer, J.D., Caruso, D.R., \& Salovey, P. (1999). Emotional intelligence meets standards for traditional intelligence. Intelligence, 27, 267-298. https://doi.org/10.1016/S0160-2896(99)00016-1

Meyer, J.W., \& Bromley, P. (2013). The worldwide expansion of 'organization'. Sociological Theory, 31(4), 366-389. https://doi.org/10.1177/0735275113513264

Mor Barak, M. (2011). Managing diversity: Toward a globally inclusive workplace. Thousand Oaks, CA: Sage.

Nkomo, S., \& Stewart, M. (2006). Diverse identities in organizations. In S. Clegg, C. Hardy, T. Lawrence, \& W. Nord (Eds.), The SAGE handbook of organization studies. London: SAGE Publications Ltd. https://doi.org/10.4135/9781848608030.n18

Osibanjo, O.A., Salau, O.P., Falola, H.O., \& Oyewunmi, A.E. (2016). Workplace stress: Implications for organizational performance in a Nigerian public university. Business Theory \& Practice, 17, 261-269.

Osland, J.S., Kolb, D.A., \& Rubin I.M. (2001). Organizational behavior: An experiential approach. Upper Saddle River, NJ: Prentice Hall.

Owoyemi, O., Elegbede, T., \& Gbajumo-Sherriff, M. (2011). Age diversity and the future of workforce in Nigeria. European Journal of Economics, Finance and Administrative Sciences, 30, 65-75.

Oyewunmi, A.E., Osibanjo, O.A., \& Adeniji, A.A. (2016). Emotional intelligence and academic performance of undergraduates: Correlations, implications and interventions. Mediterranean Journal of Social Sciences, 7(1), $509-516$.

Oyewunmi, A.E., Oyewunmi, O.A., Ojo, S.I., Oludayo, O.A. (2015). Leaders' emotional intelligence and employees' performance: A case in Nigeria's public healthcare sector. International Journal of Human Resource Studies, 5(3), 23-37. https://doi.org/10.5296/ijhrs.v5i3.7854

Oyewunmi, O.A., \& Oyewunmi, A.E. (2014). Collective bargaining in Nigeria's public healthcare sector: Evidences for an inclusive approach. Research on Humanities and Social Sciences, 4(23), 20-26.

Payne, W.L. (1985). A study of emotion: Developing emotional intelligence, self-integration, relating to fear, pain and desire. Dissertation Abstracts International, 47. Doctoral Dissertation at the Union Graduate School, Cincinnati, $\mathrm{OH}$.

Pearlman, K., \& Barney, M.F. (2000). Managing selection in changing organizations: Human resource strategies. San Francisco: Jossey-Bass.

Popoola, S.O., \& Zaid, Y.A. (2015). Effective leadership, self-efficacy, emotional intelligence, information acquisition and utilization of managers in packaging companies in Nigeria. Information and Knowledge Management, 5(1), 140-149.

Reilly, A.H., \& Karounos, T.J. (2009). Exploring the link between emotional intelligence and cross-cultural leadership effectiveness. Journal of International Business and Cultural Studies, 1, 1-13.

Reisinger, Y. (2009). International tourism: Cultures and behaviour. USA: Butterworth - Heinemann. 
Robinson, W.L.C. (1974). Conscious competency - The mark of a competent instructor. The Personnel Journal Baltimore, 53, 538-539.

Saberi, M.A. (2012). The role of emotional intelligence in enhancing inter-cultural sensitivity. Unpublished doctoral thesis, United Kingdom: Brunel University.

Salovey, P., \& Mayer, J. D. (1990). Emotional intelligence. Imagination, Cognition and Personality, 9(3), 185-211. https://doi.org/10.2190/DUGG-P24E-52WK-6CDG

Saxena, A. (2014). Workforce diversity: A key to improve productivity. Procedia Economics and Finance, 11, 76-85. https://doi.org/10.1016/S2212-5671(14)00178-6

Schutte, N.S., Malouff, J.M., Hall, L.E., Haggerty, D., Cooper, J.T., Golden, C., et al. (1998). Development and validation of a measure of emotional intelligence. Personality and Individual Differences, 25, 167-177. https://doi.org/10.1016/S0191-8869(98)00001-4

Simms, C. (2013). Voice: The importance of diversity in healthcare. International Journal of Clinical Practice, 67(5), 391-396. https://doi.org/10.1111/ijcp.12134

Smith, J. (Ed.). (2009). Well said! Great speeches in American history. Washington, DC: E \& K Publishing.

Society for Human Resource Management (2009). Global diversity and inclusion: Perceptions, practices and attitudes. Alexandria, VA: SHRM.

Stough, C., Palmer, B.R., Gardner, L., Papageorgiou, V., \& Redman, S. (2002). The development of a workplace measure of emotional intelligence - The Swinburne University Emotional Intelligence Test (SUEIT). Symposium presented at the Third Conference on Emotional and Organizational Life, Gold Coast, Queensland, Australia, 14-16 June.

Tajfel, H., \& Turner, J.C. (1986). The social identity theory of intergroup behaviour. Chicago, IL: Nelson-Hall.

Tajfel, H., Flament, C. Billing, M.G., \& Bundy, F. (1971). Social categorization and intergroup behaviour. European Journal of Social Psychology, 1, 149-177. https://doi.org/10.1002/ejsp.2420010202

The World Bank (2013). World Bank annual report. World Bank.

Thompson, R.A. (1994). Emotion regulation: A theme in search of definition. Monographs for the Society for Research in Child Development, 59, 25-52. https://doi.org/10.2307/1166137

Weinert, F.E. (2001) Concept of competence: A conceptual clarification. In D. S. Rychen, \& L. H. Salganik (Eds.), Defining and selecting key competencies (pp. 45-65). Seattle, WA: Hogrefe \& Huber.

Woodruffe, C. (2001). Promotional intelligence. People Management, 11, 26-29.

Zeidner, M., Matthews, G., \& Roberts, R. (2004). Emotional intelligence in the workplace: A critical review. Applied Psychology, 53(3), 371-399. https://doi.org/10.1111/j.1464-0597.2004.00176.x

Zeman, J., Cassano, M., Perry-Parrish, C., \& Stegall, S. (2006). Emotion regulation in children and adolescents. Journal of Developmental and Behavioral Pediatrics, 27, 155-168. https://doi.org/10.1097/00004703-200604000-00014

Intangible Capital, 2018 (www.intangiblecapital.org)

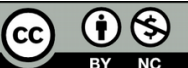

Article's contents are provided on an Attribution-Non Commercial 4.0 Creative commons International License. Readers are allowed to copy, distribute and communicate article's contents, provided the author's and Intangible Capital's names are included. It must not be used for commercial purposes. To see the complete license contents, please visit https://creativecommons.org/licenses/by-nc/4.0/. 